\title{
Secretion systems and signal exchange between nitrogen-fixing rhizobia and legumes
}

\author{
Matthew S. Nelson and Michael J. Sadowsky* \\ BioTechnology Institute, Department of Soil, Water and Climate, University of Minnesota, Saint Paul, MN, USA
}

The formation of symbiotic nitrogen-fixing nodules on the roots and/or stem of leguminous plants involves a complex signal exchange between both partners. Since many microorganisms are present in the soil, legumes and rhizobia must recognize and initiate communication with each other to establish symbioses. This results in the formation of nodules. Rhizobia within nodules exchange fixed nitrogen for carbon from the legume. Symbiotic relationships can become non-beneficial if one partner ceases to provide support to the other. As a result, complex signal exchange mechanisms

OPEN ACCESS

Edited by:

Etienne Yergeau,

National Research Council, Canada

Reviewed by:

Katharina Pawlowski,

Stockholm University, Sweden

Erik Limpens,

Wageningen University, Netherlands

*Correspondence:

Michael J. Sadowsky,

BioTechnology Institute, Department of Soil, Water and Climate, University of Minnesota, 140 Gortner Laboratory, 1479 Gortner Avenue, Saint Paul, MN 55108, USA sadowsky@umn.edu

Specialty section: This article was submitted to Plant Biotic Interactions, a section of the journal Frontiers in Plant Science

Received: 02 March 2015 Accepted: 19 June 2015 Published: 01 July 2015

Citation:

Nelson MS and Sadowsky MJ (2015)

Secretion systems and signal exchange between nitrogen-fixing rhizobia and legumes.

Front. Plant Sci. 6:491. doi: 10.3389/fp/s.2015.00491 have evolved to ensure continued, beneficial symbioses. Proper recognition and signal exchange is also the basis for host specificity. Nodule formation always provides a fitness benefit to rhizobia, but does not always provide a fitness benefit to legumes. Therefore, legumes have evolved a mechanism to regulate the number of nodules that are formed, this is called autoregulation of nodulation. Sequencing of many different rhizobia have revealed the presence of several secretion systems - and the Type III, Type IV, and Type $\mathrm{VI}$ secretion systems are known to be used by pathogens to transport effector proteins. These secretion systems are also known to have an effect on host specificity and are a determinant of overall nodule number on legumes. This review focuses on signal exchange between rhizobia and legumes, particularly focusing on the role of secretion systems involved in nodule formation and host specificity.

Keywords: rhizobia, nodulation, symbiosis, signal exchange, type III secretion system, type IV secretion system, type VI secretion system, effector proteins

\section{Introduction}

Plants interact with many different types of microbes, and these associations can be pathogenic, mutualistic, or commensal in nature. The type of relationship between a specific microbe and plant can vary based on external factors, such as changes in environment, or due to intrinsic factors of both organisms. Both pathogenic and mutualistic interactions are dependent on communication between host and microbe and are primarily based on signal exchange (Tseng et al., 2009). The symbiotic relationship between rhizobia and legumes has long been a focus of study because of the nitrogen fixation that occurs during the symbiosis. This symbiosis requires the rhizobia to be in close physical proximity to the legume to allow for exchange of nutrients. Nitrogen is essential for all agricultural crops, but only legumes can access nitrogen from the atmosphere through symbiosis with rhizobia. Signal exchange between rhizobia and legumes has been studied as a potential process regulating symbiosis on non-legume plants and a mechanism by which to increase nitrogen fixation in legumes. 
The symbiosis between legumes and rhizobia has evolved to incorporate many different levels of signal exchange, from initial contact to senescence. Two primary reasons for this signal exchange are to distinguish between symbionts and pathogens and to ensure mutualism through the exchange of carbon and fixed nitrogen. The line between symbiont and pathogen is not always clear, as both partners can have a fitness benefit to alter the relationship to their advantage. Symbiotic associations may shift from mutually beneficial to pathogenic or vice versa, such as in the case of the plant pathogen Argobacterium, having a common ancestral history with rhizobia. It has been suggested that rhizobia can be viewed as refined pathogens (Deakin and Broughton, 2009). The symbiotic relationship between rhizobia and legumes can easily turn pathogenic if the plants loses the ability to regulate the total number of nodules formed or the rhizobia form nodules that do not fix nitrogen - with the plant experiencing decreased fitness by providing too much carbon to the rhizobia (Herridge and Rose, 2000; Kiers et al., 2003). Co-evolution between rhizobia and legumes is more complex because of rhizobia selection can oscillate between pathogen and symbiont.

The evolutionary arms race between pathogens and plants has long been studied (Jones and Dangl, 2006). Pathogens develop new strategies for creating infections, such as evolving secretion systems to alter the host cell. In response, plants develop new strategies for detecting pathogens, such as microbe-associated molecular patterns (MAMPs), and R genes (Dodds and Rathjen, 2010). Sequencing of various rhizobial strains has shown the presence of secretion systems similar to those used by pathogens to transfer proteins into the hosts' cytosol. These secretion systems include the Type III (T3SS), Type IV (T4SS), and Type VI secretion systems (T6SS; Fauvart and Michiels, 2008). The evolutionary presence of these secretion systems suggests that while rhizobia and legumes co-evolved a system allowing establishment and maintenance of a symbiosis, a relationship similar to a pathogen/plant interaction also co-evolved. This review focuses on legume-rhizobia signal exchange that occurs during nodule formation, plant mechanisms for limiting nodule number, and potential strategies used by rhizobia to overcome the plants ability to limit nodule number using the T3SS, T4SS, or T6SS.

\section{Signaling Exchange During Nodule Formation}

Rhizobia are free-living, soil saprophytes, prior to symbiosis with plants in the family Leguminosae. Rhizobia, once inoculated into soil, can persist at low levels in the absence of a suitable host (Howieson, 1995). The plant initiates symbiosis by secreting flavonoids, which are detected by the rhizobia. Flavonoids vary by plant species and are only recognized by certain, yet specific, rhizobial species, offering the first level of symbiosis specificity (Hassan and Mathesius, 2012). The flavonoids diffuse across the membrane of the rhizobia and induce synthesis of the NodD protein to activate transcription of other genes involved in nodulation including nod factor (NF) production (Wang et al., 2012). NFs are a primary signal molecule produced by bacteria and detected by the plant to induce nodule organogenesis. Structurally NFs are lipochitooligosaccharides (LCOs) with a chitin oligomer backbone (Oldroyd and Downie, 2008). The nod $A B C$ genes encode for the proteins required to make the core NF structure and are conserved across all rhizobia species, except two Aeschynomene-infective species (Perret et al., 2000; Giraud et al., 2007). The NF core is then modified by species-specific proteins resulting in various substitutions on both the reducing and non-reducing end, including glycosylation and sulfation (Long, 1996). These substitutions are specific for each host legume and offer another level of symbiosis specificity (Dénarié et al., 1996; Long, 1996). Many surface polysaccharides are also involved in symbiosis specificity including lipopolysaccharides (LPSs), extracellular polysaccharides (EPSs), and capsular poylsaccharides (KPSs; Deakin and Broughton, 2009). The specific structure of LCOs is known to be important for recognition by host nod factor receptors (NFRs), which are receptor kinases containing lysin motifs (LysM; Radutoiu et al., 2007). Leucine rich repeat receptor-like kinases (LRR-RLKs) are also involved in NF perception and signaling, which results in nodule formation (Endre et al., 2002).

Root hair curling and crack entry are the two infection mechanisms used by rhizobia. Crack entry involves rhizobia entering through cracks at the lateral root bases or stems (Goormachtig et al., 2004). Root hair curling involves recognition of NFs, this recognition results in both calcium spiking and the curling of the root hair (Esseling et al., 2003). This is thought to involve a change in the plant cells' polarity, resulting in a new growing direction of the root hair tip (Gage, 2004). The infection chamber enlarges and changes into a globular apoplastic space. Next, root tip growth in switched from radial to polar tip elongation (Fournier et al., 2015). The continued growth of the infection thread is dependent on NF specificity as well as EPS (Jones et al., 2007). Both the epidermis and the cortex recognize NFs, the epidermis regulates rhizobia infection and the root cortex is responsible for nodule formation (Oldroyd and Downie, 2008). Cortical cells develop into a nodule primordium. When the infection thread reaches the nodule primordium, the rhizobia enter into the inner cells and become encapsulated within a peri-bacteroid membrane (Oldroyd and Downie, 2008).

There are two main types of nodules, indeterminate and determinate, and this is determined by the legumes. For indeterminate nodules, cell division typically begins in the inner cortex (Ferguson et al., 2010). Indeterminate nodules maintain a persistent meristem and form distinct zones, including rhizobia invasion, active nitrogen fixation and senescence (Udvardi and Poole, 2013). These zones contain rhizobia in various developmental states with the proximal zone losing the ability to reproduce (Mergaert et al., 2006). Legumes belonging to the inverted repeat-lacking clade manipulate bacterial differentiation through secretion of cysteine-rich peptides, which induce membrane permeabilization, endoreduplication, and loss of independent viability (Mergaert et al., 2006; Van de Velde et al., 2010; Oldroyd et al., 2011). In contrast, cell division begins in the outer cortex for determinate nodules (Ferguson et al., 2010). Determinate nodules do not have a persistent meristem and form 
a homogenous group of rhizobia with full viability (Saeki, 2011). In mature nodules, plants exchange small carbon molecules for ammonia with the rhizobia. Another important aspect of symbiosis regulation is amino acid exchange and cycling between the plant and the rhizobia. During symbiosis some plants secrete branched chained amino acids, into the peribacteroid space, and in return the rhizobia secrete aspartate and, in some cases, alanine. Rhizobial biosynthesis of branched chained amino acids is shut down during symbiosis, preventing the use of ammonium by rhizobia and allowing the plant to incorporate ammonium into aspartate to produce asparagine (Lodwig et al., 2006; Prell et al., 2009).

After many weeks of plant growth, nodules begin to senescence, with a maximum lifespan well-short of that of the host plant (Puppo et al., 2005). Dark stress, water stress, defoliation, or addition of nitrate can initiate premature nodule senescence (González et al., 1998; Matamoros et al., 1999; Hernández-Jiménez et al., 2002). This suggest that the plant controls the duration of the symbiosis by being able to induce nodule senescence. These external factors are thought to lead to an increase in reactive oxygen species, which initiates senescence (Puppo et al., 2005). During nodule senescence, the host plant initiates plant cell death and some rhizobia not in the symbiosome survive this process and return to a saprotrophic state in the soil (Hernández-Jiménez et al., 2002).

\section{Plant Signaling Limits Nodule Number}

The symbiotic relationship between rhizobia and legumes has the potential to become pathogenic if the plant loses the ability to regulate the total number of nodules or perceives the rhizobia as a pathogen. Rhizobia will generally initiate nodule formation because a symbiotic relationship always has a fitness benefit for the rhizobia. However, if the plant forms too many nodules then there is a negative effect on vegetative growth and yield (Herridge and Rose, 2000; Takahashi et al., 2003; Matsunami et al., 2004). Legumes use a process called autoregulation of nodulation (AON) to control nodule number by preventing new nodule formation (Mortier et al., 2012). The AON is thought to involve a root-derived signal being transported to the shoot, which induces a shoot-derived signal to be transported to the root - this inhibits nodule formation (Suzaki et al., 2015).

After nodule formation, the plant cell begins to produce CLV3/ESR-related (CLE) peptides. CLE peptides are thought to be the signal molecule transported from the roots to the shoot as part of the signaling pathway involved in AON (Reid et al., 2011, 2013). The CLE-RS2 is a post-translationally arabinosylated glycopeptide derived from the CLE domain, and if externally added CLE-RS2 sufficient to inhibit nodule formation (Okamoto et al., 2013). The CLE-peptides are recognized by LRR-RLKs (Krusell et al., 2002; Nishimura et al., 2002; Sasaki et al., 2014). These receptors then cause a signal cascade which results in cytokinins being transported from the shoot to the root, which could act as the shoot-derived signal to suppress nodule formation (Sasaki et al., 2014). In the Lotus japonicas tml mutant, shoot-applied cytokinin does not suppress nodule formation (Sasaki et al., 2014). This implies that TML acts downstream of cytokinins, and may act directly in the root cells to suppress nodulation. TML encodes a Klech repeat-containing F-box protein and has been hypothesized to target a protein for degradation which has a positive role in nodule formation (Takahara et al., 2013; Suzaki et al., 2015).

Autoregulation of nodulation signaling is a complex process involving numerous steps, some of which are still unknown. Disruption of AON at many different steps has been shown to results in a hyper-nodulation phenotype. This suggests that the AON signaling process could be potential targets for rhizobia to disrupt, in order to increase nodule formation. Inhibition of AON, could result in the symbiotic relationship between rhizobia and legumes becoming a pathogenic one (Herridge and Rose, 2000).

\section{Bacterial Secretion Systems}

Bacteria use a wide variety of secretion systems to export proteins and other compounds across their membranes and cell walls. Interaction with the external environment is vital to bacterial survival, and many different transmembrane channels have evolved independently to fulfill this need (Wooldridge, 2009). There have been reports of up to many different secretion systems, but only the first seven have been significantly investigated (Tseng et al., 2009). These secretion systems have evolved independently, each containing a different set of core proteins. Each secretion system itself diverged into unique subfamilies based on different functions. The T1SS, T2SS, and T5SSs are thought to simply transport proteins and compounds outside of the cell. The T3SS, T4SS, and T6SSs contain subfamilies with the ability to transport effector proteins into the cytosol of eukaryotic cells (Wooldridge, 2009). This is important because it allows for the direct communication with, and modification of, the eukaryotic cytosol. These three secretion systems are well-understood for their role in pathogenesis as key factors in virulence and, in some cases, symbiosis.

\section{Rhizobia Secretion Systems}

As discussed above, rhizobia enter into unique symbioses with eukaryotic cells, through the formation of relationship with legumes. Sequencing of rhizobia strains has shown that they typically contain multiple secretion systems. However, the presence of these systems in the bacterial genome does not mean they have a role in symbiosis. Rhizobia surface polysaccharides (LPS) have been known to suppress plant immune responses, but the T3SS and T4SS have also been speculated to have a role in suppressing the plant immune system (Masson-Boivin et al., 2009).

The T3SS and T4SS are each sub-divided into seven families based on function and protein homology (Wooldridge, 2009; 
Sugawara et al., 2013). The T3SS, T4SS, and T6SSs have been identified throughout various rhizobial genera and sequence homology shows similarity between known secretion systems used by bacterial pathogens. Specifically, sequence analysis of Sinorhizobium has shown that they can contain either the T3SS, T4SS or the T6SS, but typically only have one involved in symbiosis per strain (Sugawara et al., 2013). The T3SS, T4SS, and T6SS have all been shown to be involved in symbiosis and translocate effector proteins during symbiosis. These effector proteins could potentially have a function by promoting nodule formation, disrupting $\mathrm{AON}$, or suppressing the plant's immune response during invasion. In plant pathogens, the T3SS effectors have been shown to target and suppress the plant immune response (Macho and Zipfel, 2015). Deletion of a specific subfamily of the T3SS or the T4SS has been shown to reduce nodule number and affect host range specificity (Sugawara et al., 2013; Tampakaki, 2014). However, their role in symbiosis is still not very well-understood.

\section{Type III Secretion System}

The T3SS is a structure composed of 20-27 different proteins, and this transporter is responsible for secretion of type III effector proteins (T3Es; Ghosh, 2004; Tampakaki, 2014). Approximately $50 \%$ of proteins involved in secretion system channel formation are conserved in most T3SSs (Ghosh, 2004). These proteins are generally found clustered in a $22-50 \mathrm{~kb}$ pathogenicity island (Tampakaki, 2014). The T3SS complex spans the bacterial inner and outer membrane as well as the hosts' membranes and allows protein transport into the host. Regions flanking the pathogenicity island can contain genes that encode for effector proteins, but most effector genes are scattered throughout the genome (Lindeberg et al., 2008).

Many different variations of T3SS, with varying functions, are found throughout the kingdom of bacteria. In the literature, the T3SS is first grouped by species, and then grouped by homology. The genes encoding the rhizobial T3SSs are called rhc (Rhizobium conserved). The rhc are further subdivided into four families based on phylogenetic analyses, Rhc-1 to Rhc-4 (Gazi et al., 2012). Of these four families, only Rhc-I has been showed to be involved in symbiosis (Tampakaki, 2014). The functions of the other families are still unknown. The T3SS is among the best studied secretion systems in rhizobia due to the wide species distribution of Rhc-1 and its role in symbiosis.

\section{T3SS - Rhc-I Effect on Symbiosis}

Early studies of the T3SS - Rhc-1 focused on knocking out the entire system through deletions or disruption of core genes. A diverse range of rhizobial species are known to contain a functional T3SS - Rhc-1 and are listed in Table 1. The influence of

TABLE 1 | Symbiotic effect of the T3SS - Rch-1 in rhizobia.

\begin{tabular}{|c|c|c|c|c|}
\hline $\begin{array}{l}\text { Strain of rhizobia } \\
\text { with T3SS - Rch-1 }\end{array}$ & $\begin{array}{l}\text { Secreted } \\
\text { proteins }\end{array}$ & Positive effect on symbiosis & $\begin{array}{l}\text { Negative effect on } \\
\text { symbiosis }\end{array}$ & Reference \\
\hline $\begin{array}{l}\text { Rhizobium etli } \\
\text { CNPAF512 }\end{array}$ & 2 & Phaseolus vulgaris & Unknown & $\begin{array}{l}\text { Michiels et al. (1995), Fauvart and } \\
\text { Michiels (2008) }\end{array}$ \\
\hline $\begin{array}{l}\text { Bradyrhizobium elkanii } \\
\text { USDA61 }\end{array}$ & 8 & $\begin{array}{l}\text { Macroptilium atropurpureum, Glycine } \\
\text { max ev. Clark, G. max cv. Enrei }\end{array}$ & $\begin{array}{l}\text { Vigna radiata cv. KPS1, G. max } \\
\text { cv. Hill }\end{array}$ & $\begin{array}{l}\text { Okazaki et al. (2009), Okazaki et al. } \\
\text { (2013) }\end{array}$ \\
\hline $\begin{array}{l}\text { Mesorhizobium loti } \\
\text { MAFF303099 }\end{array}$ & 8 & $\begin{array}{l}\text { Lotus glaber, Lotus japonicus, Lotus } \\
\text { corniculatus subsp. frondsus, Lotus } \\
\text { filicaulis }\end{array}$ & $\begin{array}{l}\text { Leucaena leucocephala, Lotus } \\
\text { halophilus, Lotus peregrinus } \\
\text { var. carmeli, Lotus subbiflorus }\end{array}$ & $\begin{array}{l}\text { Hubber et al. (2004), Sánchez et al. } \\
\text { (2009), Sánchez et al. (2012), Okazaki } \\
\text { et al. (2010) }\end{array}$ \\
\hline $\begin{array}{l}\text { Sinorhizobium fredii } \\
\text { NGR234 }\end{array}$ & 15 & $\begin{array}{l}\text { Tephrosia vogelii, Flemingia congesta, } \\
\text { Lablab purpureus }\end{array}$ & $\begin{array}{l}\text { L. leucocoephala, Pachyrhizus } \\
\text { tuberosus, Crotalaria juncea }\end{array}$ & $\begin{array}{l}\text { Viprey et al. (1998), Skorpil et al. (2005), } \\
\text { Kambara et al. (2009), Kimbrel et al. } \\
\text { (2013) }\end{array}$ \\
\hline S. fredii $\mathrm{HH} 103$ & 8 & $\begin{array}{l}\text { G. max cv. Peking, Heinong 33, } \\
\text { Kochi, and Williams, Glycyrrhiza } \\
\text { uralensis }\end{array}$ & Erythrina variegata & $\begin{array}{l}\text { Rodrigues et al. (2007), López-Baena } \\
\text { et al. (2008) }\end{array}$ \\
\hline S. fredii USDA207 & 13 & Unknown & Unknown & Kimbrel et al. (2013) \\
\hline S. fredii USDA257 & 13 & $\begin{array}{l}\text { G. max cv. Peking and Williams, } \\
\text { M. atropurpeum }\end{array}$ & G. max cv. McCall, E. variegata & $\begin{array}{l}\text { Krishnan et al. (2003), De Lyra et al. } \\
\text { (2006), Kimbrel et al. (2013) }\end{array}$ \\
\hline $\begin{array}{l}\text { Bradyrhizobium } \\
\text { japonicum USDA6 }\end{array}$ & 33 & Unknown & Unknown & Kimbrel et al. (2013) \\
\hline B. japonicum USDA110 & 36 & $\begin{array}{l}\text { M. atropurpureum G. max cv. } \\
\text { Williams }\end{array}$ & V. radiata cv. KPS2 & $\begin{array}{l}\text { Krause et al. (2002), Wenzel et al. } \\
\text { (2010), Kimbrel et al. (2013) }\end{array}$ \\
\hline B. japonicum USDA122 & 31 & Unknown & Unknown & Kimbrel et al. (2013) \\
\hline B. japonicum USDA123 & 32 & Unknown & Unknown & Kimbrel et al. (2013) \\
\hline B. japonicum USDA124 & 33 & Unknown & Unknown & Kimbrel et al. (2013) \\
\hline $\begin{array}{l}\text { Cupriavidus } \\
\text { taiwanensis LMG19424 }\end{array}$ & Unknown & Unknown & L. leucocephala & Saad et al. (2012) \\
\hline
\end{tabular}

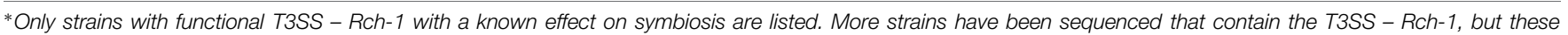

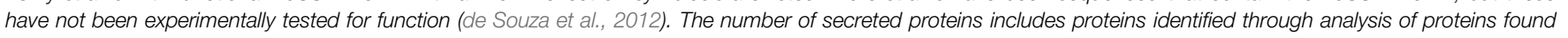
externally after induction of the T3SS, and proteins shown to be transported into the cytosol of Arabidopsis. 
T3SSs on nodulation can vary from positive, in which nodulation is increased, to negative, in which nodulation is reduced. In Sinorhizobium fredii strain NGR234, the T3SS has both a positive and negative affect on multiple different legume species, but may also have a neutral phenotype, where nodulation is not affected, for example on Vigna unguiculata (Viprey et al., 1998; Skorpil et al., 2005; Kambara et al., 2009). Similarly, rhizobia with the T3SS - Rch-1 show host-dependent phenotypes in regard to nodulation efficiency. This could explain why the T3SS - Rch-1 is found in many genera of rhizobia, but is not ubiquitous at the strain level.

The horizontal transfer of the T3SS could be an important evolutionary driver toward symbiosis or pathogenesis between bacteria and plants. The pathogen Ralstonia solanacearum was shown to be unable to nodulate Mimosa pudica when the symbiotic plasmid of Cupriavidus taiwanensis was added, but was able to nodulate $M$. pudica if the T3SS was also deleted (Marchetti et al., 2010). This shows that the T3SS can prevent symbiosis. However, deleting the T3SS effector protein GALA7 prevented pathogenic infection of Medicago truncatula (Angot et al., 2006). This shows that the T3SS in $R$. solanacearum is required for pathogensis. In addition, C. taiwanensis was able to nodulate Leucaena leucocephala when the T3SS in C. taiwanensis was deleted (Saad et al., 2012). These examples show how the presence of the T3SS can restrict host range by preventing symbiosis, and could have a role in bacteria transitioning from a symbiont to a pathogen.

\section{Regulation of the T3SS - Rhc-1}

Expression of the T3SS is induced by plant flavonoid recognition through production of the transcriptional activator TtsI (Viprey et al., 1998; Krause et al., 2002; Kobayashi et al., 2004). TtsI initiates transcription of the T3SS genes and effector proteins by binding to specific cis-elements, known as tts boxes (Wassem et al., 2008). The number and location of $t$ ts boxes varies between species and Bradyrhizobium japonicum USDA110 is known to have 52 different $t$ ts boxes. Proteins secreted by the T3SS are found downstream of $t$ ts boxes.

There is not a consensus motif for proteins secreted through the T3SS. However, the signal sequence is typically found in the first $\sim 15$ amino acids, on the N-terminus, of translocated proteins (Ghosh, 2004). In addition not all gene transcription activated by $t$ ts boxes, are effector proteins translocated through the T3SS; some can have other roles in symbiosis such as the production of rhamnose-rich polysaccharides (Marie et al., 2004). These rhamnose-rich polysaccharides were shown to be surface LPSs, important in nodule formation, independent of the T3SS (Broughton et al., 2006). This suggests an interesting link between secretion systems and surface polysaccharides involved in nodule formation specificity.

\section{Proteins Secreted by the T3SS - Rhc-1}

Early studies to identify proteins secreted through the T3SS focused on using flavonoids to induce expression in culture and compared the external proteins to those found in a T3SS mutant. However, these experiments did not show translocation into the host cytosol. This led to uncertainty as to whether an identified protein was an effector protein, acting inside the plant cell. A new, high-throughput technique was used to properly identify proteins that translocate through the T3SS as well as to identify effector proteins (Kimbrel et al., 2013). However, this technique did not test for effector translocation into legumes, but rather the proxy of translocation through Pseudomonas syringae pv. tomato DC3000 into Arabidopsis Col-O. The T3E candidates are fused to $\triangle 79$ AvrRpt2, which induces a hypersensitive response (HR) in Arabidopsis. Using this technique on three different strains of $S$. fredii and B. japonicum, between 13 and 36 T3Es per strain were identified (Kimbrel et al., 2013). The T3Es can vary between species and strains, but members of the same species tend to use very similar effector proteins.

Proteins secreted by the T3SS can be separated into two categories - pilus forming and effectors. Proteins involved in pilus formation are secreted through the channel to assist in forming a channel through the plants cell wall or plasma membrane. NopA, NopB, and NopX are thought to be involved in the terminal formation of the T3SS, forming a pilus that penetrates the plant's cell wall and plasma membrane (Lorio et al., 2004; Deakin et al., 2005; Saad et al., 2005, 2008). The other secreted proteins are thought to be effector proteins, but few of these proteins have a predicted function in planta (Table 2).

As shown in Table 1, deleting the T3SS can have a positive or negative effect on symbiosis. The T3SS is simply the means of transport for effector proteins. Deleting the T3SS prevents effector protein transport. These effector proteins play key roles in symbiosis. Despite having a known effect on symbiosis, none of these effector proteins has been expressed in legumes. Only the effectors NopL, NopT, and NopM have all been expressed in eukaryotic cells. NopL was first shown to be phosphorylated by plant kinases (Bartsev et al., 2003). Next, NopL was shown to interfere with mitogen-activated protein kinase (MAPK) signaling in Nicotiana tabacum. MAPK signaling is involved pathogen recognition in both basal plant defense and R-mediated resistance (Pedley and Martin, 2005). Part of the plant defensive response is the induction of HR. The plant pathogen P. syringae uses effector proteins AvrPto and AvrPtoB to interrupt MAPK signaling by degrading the plant protein FLS2 (Göhre et al., 2008; Shan et al., 2008). Overexpression of MAPK signaling in plants induces HR to prevent pathogen infections. NopL was shown to suppress cell death induced by the overexpression of MAPK signaling (Zhang et al., 2011). NopT when expressed in N. tabacum or Arabidopsis thaliana elicited a strong HR response and necrotic symptoms. The authors did suggest that it could function as a protease and had similarity to the effector family YopT - AvrPphB (Dai et al., 2008). AvrPphB is an effector in P. syringae and functions as an autoprotease, cleaving itself to expose a myristolation site (Puri et al., 1997; Shao et al., 2002). The addition of myristoyl groups after cleavage, target AvrPphB to the cell membrane (Nimchuk et al., 2000). NopT has been shown to have cysteine protease activity and may use autoproteolysis for target to cell membranes, but its role is still uncertain (Fotiadis et al., 2012). NopM was shown to possess E3 ubiquitin ligase activity. Furthermore, when this ability was lost through a point mutation, 
TABLE 2 | Predicted functions of T3SS secreted proteins.

\begin{tabular}{|c|c|c|c|}
\hline $\begin{array}{l}\text { T3SS - Rch-1 } \\
\text { secreted proteins }\end{array}$ & Strains containing homolog & Predicted function & Reference \\
\hline NopA & $\begin{array}{l}\text { B. japonicum USDA110, M. loti } \\
\text { MAFF303099, S. fredii NGR234, S. fredii } \\
\text { HH103, S. fredii USDA257 }\end{array}$ & $\begin{array}{l}\text { Part of the T3SS extracellular pilus which spans } \\
\text { the plants cell wall }\end{array}$ & Deakin et al. (2005), Saad et al. (2008) \\
\hline NopB & $\begin{array}{l}\text { B. japonicum USDA110, M. loti } \\
\text { MAFF303099, S. fredii NGR234, S. fredii } \\
\text { HH103, S. fredii USDA257 }\end{array}$ & $\begin{array}{l}\text { Part of the T3SS extracellular pilus which spans } \\
\text { the plants cell wall }\end{array}$ & Saad et al. (2005), Saad et al. (2008) \\
\hline NopD & S. fredii $\mathrm{HH} 103$ & Homology to a predicted C48 cysteine peptidase & Hubber et al. (2004), Rodrigues et al. (2007) \\
\hline NopL & $\begin{array}{l}\text { B. japonicum USDA110, S. fredii NGR234, } \\
\text { S. fredii HH103, S. fredii USDA257 }\end{array}$ & $\begin{array}{l}\text { Suppresses cell death induced by } \\
\text { mitogen-activated protein kinase (MAPK) }\end{array}$ & Zhang et al. (2011) \\
\hline NopM & $\begin{array}{l}\text { B. japonicum USDA110, S. fredii } \\
\text { NGR234, S. fredii } \mathrm{HH} 103\end{array}$ & $\begin{array}{l}\text { E3 ubiquitin ligase, thought to be involved in } \\
\text { protein-protein interactions }\end{array}$ & Rodrigues et al. (2007), Xin et al. (2012) \\
\hline NopP & $\begin{array}{l}\text { S. fredii NGR234, R. etli CNPAF512, } \\
\text { S. fredii } \mathrm{HH} 103, \text { S. fredii USDA257 }\end{array}$ & Phosphorylated by plant kinases & Skorpil et al. (2005) \\
\hline NopT & S. fredii NGR234 & Cysteine protease & Fotiadis et al. (2012) \\
\hline NopX & $\begin{array}{l}\text { M. loti MAFF303099, S. fredii NGR234, } \\
\text { S. fredii HH103, S. fredii USDA257 }\end{array}$ & $\begin{array}{l}\text { Terminal part of the T3SS extracellular pilus which } \\
\text { spans the plants cell wall }\end{array}$ & Saad et al. (2008) \\
\hline Mlr6361 & M. loti MAFF303099 & Shikimate kinase & Sánchez et al. (2009) \\
\hline
\end{tabular}

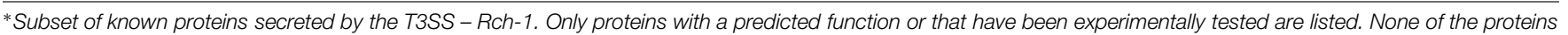
have been tested in legumes, but some have been tested in planta in Nicotiana tabacum.

the positive effects on nodule formation were also lost (Xin et al., 2012).

Even though the function of many specific proteins has not been determined, the accumulated effect of the T3SS effector proteins can be determined through deletion of the entire secretion system. Bradyrhizobium elkanii, containing the T3SS, but not the T3SS mutant, was shown to increase the transcription of two genes in the roots of a soybean line deficient in NF recognition (Okazaki et al., 2013). These genes, ENOD40 and NIN, are involved in early nodulation regulation. This suggests that the T3SS effector proteins may be involved in up-regulating host genes involved in nodule formation. Further research is needed to more completely understand how these individual effectors are functioning in planta.

\section{Type IV Secretion System}

The T4SS-b is functionally similar to the T3SS-Rch-1 and is also involved in protein translocation, but has a separate evolutionary origin. The T4SS is generally sub-divided into three families based on function, including conjugation, DNA uptake and release, and protein translocation (Cascales and Christie, 2003). These three families can use similar core proteins to form the main channel and may share sequence similarity. Properly identifying which sub-family is present in a specific strain is key. In rhizobia, the T4SS-b shares strong homology to the VirB/VirD4 subunits found in Agrobacterium. The core structure consists of 12 proteins, VirB1-B11 and VirD4. The T4SS-b, in Agrobacterium tumefaciens, is used for translocation of both T-DNA and effector proteins (Kuldau et al., 1990; Zupan and Zambryski, 1995). The function of the T4SS-b is well-understood because of its role in plant transformation. Agrobacterium and rhizobia are closely related, and understanding of the T4SS-b in Agrobacterium has been leveraged to better understand the T4SS-b in rhizobia.

\section{T4SS-b Effect on Symbiosis}

Unlike the T3SS, there is a paucity of information regarding the role of the T4SS in symbiosis. A functional T4SS-b has only been identified in three different species (Table 3). Similar to the T3SS, the T4SS-b can have both a positive or negative effect on symbiosis. In Mesorhizobium loti R7A, nodulation on Lotus corniculatus reduced, but not completely lost, when the T4SS-b was partially deleted. This same deletion allowed M. loti R7A to gain the ability to form nodules on L. leucocephala (Hubber et al., 2004). Deleting the T4SS-b in Sinorhizobium meliloti KH46c resulted in approximately a 50\% decrease in nodule number on $M$. truncatula A17, but did not have a significant effect on M. truncatula F83005-5 (Sugawara et al., 2013). This dual positive and negative selection could explain why only 9 of 33 S. meliloti and 11 of $13 \mathrm{~S}$. medicae strains were found to contain the T4SS-b (Sugawara et al., 2013).

\section{Regulation of the T4SS-b}

Transcription of the T4SS is controlled by a two-component response regulator VirA/VirG (Stachel and Zambryski, 1986). VirA is a membrane bound kinase that phosphorylates VirG in response to external factors (Hansen et al., 1994). In contrast, VirG is a transcriptional activator that binds to vir boxes. In Rhizobium these regulators are induced by flavonoids that activate VirG (Hubber et al., 2007). Unlike the T3SS effectors, which can be present throughout the genome, T4SS tend to be near VirG (Vergunst et al., 2000; Tampakaki, 2014). Research in A. tumefaciens has identified a sequence motif, a positive charged C-terminus, present on effector proteins needed for translocation (Vergunst et al., 2005). This same sequence motif is also present on the only two effector proteins identified, Msi059 and Msi061, 
TABLE 3 | Symbiotic effect of the T4SS-b.

\begin{tabular}{|c|c|c|c|c|}
\hline Strain of rhizobia with T4SS - B & Secreted proteins & Positive effect on symbiosis & Negative effect on symbiosis & Reference \\
\hline M. loti R7A & 2 & L. corniculatus & L. leucocephala & Hubber et al. (2007) \\
\hline S. meliloti $\mathrm{KH} 35 \mathrm{c}$ & Unknown & M. truncatula A17, M. tricycla & Unknown & Sugawara et al. (2013) \\
\hline S. medicae M2 & Unknown & M. truncatula A17 & Unknown & Sugawara et al. (2013) \\
\hline
\end{tabular}

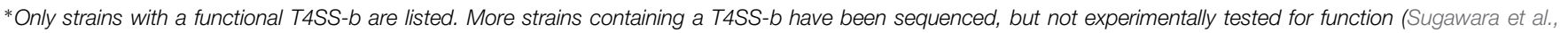
2013). Both secreted proteins in M. loti R7A, have been shown to be translocated into Arabidopsis (Hubber et al., 2004).

both in M. loti R7A (Hubber et al., 2004). VirD4 interacts with the positive charge signal sequence to transport the protein through the channel (Vergunst et al., 2005). VirD4, and the requirement of a more specific signal sequence, could result in more specificity in protein transport.

\section{Proteins Secreted by the T4SS-b}

Thus far, only two proteins have been shown to transport through the T4SS-b, Msi059, and Msi061 in M. loti R7A. The Msi059 showed partial protein sequence similarity to a $\mathrm{C} 48$ cysteine peptidase. Interestingly, the NopD T3E in S. fredii HH103 also was a predicted C48 cysteine peptidase (Rodrigues et al., 2007). The C48 cysteine peptidase family contains the protein XopD, a T3E from the plant pathogen Xanthomonas campestris (Hotson et al., 2003). XopD encodes an active cysteine protease, and functions in planta to target SUMO-conjugated proteins (Hotson et al., 2003). This interferes with the plant's ability to regulate the expression of specific proteins. Msi061 has shared protein similarity with A. tumefaciens effector VirF. The VirF interacts with the host Skp1 to facilitate protein degradation of effector proteins VirE2 and Vip1 to unbind the T-DNA after into the host cell (Schrammeijer et al., 2001; Tzfira et al., 2004). Skp1 is a core component of the E3 ubiquitin ligase, which mediates protein degradation (Schrammeijer et al., 2001). The precise activity of Msi059 and Msi061 are still unknown, but current evidence suggests a role in changing protein expression levels in planta.

\section{Type VI Secretion System}

The T6SS is among the least researched secretion system involved in protein translocation. The T6SS is known to contain different subfamilies, but the sub-families and their functions have yet to be clearly defined. The number of proteins involved in forming the core structure seem to vary and there is no known secretion signal for protein transport (Bingle et al., 2008). Additionally, how T6SS expression is regulated is unknown. Still, the T6SS is thought to play an important role in the virulence of multiple pathogens, like Burkholderia mallei (Schell et al., 2007).

\section{T6SS Effect on Symbiosis}

The sequence for the T6SS has been found in five different species of rhizobia, R. leguminosarum, B. japonicum, M. loti, S. saheli, and S. fredii (Bladergroen et al., 2003; Bingle et al., 2008; Sugawara et al., 2013). However, a functional T6SS, with an effect on symbiosis, has only been shown in R. leguminosarum. In this bacterium a negative effect on symbiosis was observed, where the T6SS prevented nodulation on Pisum sativum cv. Rondo (Bladergroen et al., 2003). A single protein was identified that is secreted through the T6SS. Sequencing of the first 50 amino acids suggested a role in ribose transport (Bladergroen et al., 2003). The effect that ribose transport has on symbiosis is unclear. More strains containing the T6SS have been identified, but not experimentally tested for function (Bingle et al., 2008; Sugawara et al., 2013).

\section{Example of Effector Involvement in Symbiosis}

Most studies have focused on deleting specific genes in the core structure, instead of the effector proteins, and observing the overall phenotypic change. This is likely due to the fact that the core genes, unlike effectors, do not vary between species. Additionally, the phenotypic effect(s) of a single effector knockout might be small, again with some strains containing 36 different T3Es. One of the most well-characterized examples of the how the T3SS functions is in S. fredii strain USDA257. In this case $S$. fredii USDA257 is both a pathogen and a symbiont.

Legumes limit nodule number, and one mechanism used is to abort nodule formation, through a process similar to HR (Vasse et al., 1993). The S. fredii USDA257 strain contains NopL, which suppresses cell death through preventing MAPK signaling from inducing HR and cell death (Bartsev et al., 2004; Zhang et al., 2011). This would, in theory, increase the total number of nodules formed. Soybeans have evolved an $\mathrm{R}$ gene, Rfg1, capable of detecting T3Es from S. fredii USDA257 (Yang et al., 2010). Rfg1 encodes a TIR-NBS-LRR disease resistance protein, which are known to recognize pathogen effectors to induce disease resistant (Belkhadir et al., 2004). In soybean lines expressing Rfg1, the plant prevents nodulation by S. fredii USDA257, but not in the T3SS knockout mutant (Trese, 1995; Yang et al., 2010). In addition S. fredii USDA257 formed almost twice as many nodules on the soybean lines without the Rfg1 and the recessive rj2 genes as did the T3SS knockout mutant, on three different soybean lines (Yang et al., 2010). Taken together, the T3SS, including NopL, can increase nodulation in soybean. Recognition of the T3Es, by Rfg1, results in complete prevention of nodulation. NopL restricts the plant's ability to prevent infection and nodule formation, and rhizobia become partially pathogenic through using this strategy. The specific protein which is recognized by Rfg1, either directly or indirectly, is still not known. Though this is just one example, it is consistent 
with observations from other studies showing both the positive and negative effects of the T3SS as listed in Table 1. This dual selection also explains why the T3SS is not found in all strains of Rhizobia.

\section{Proposed Model}

Most of these studies were done by deleting the entire secretion system, versus knocking out only specific effector proteins. Secretion systems are not found in all strains for any species of rhizobia. Typically, if the T3SS or T4SS has a positive effect on nodulation, then deletion of the T3SS results in $\sim 40-60 \%$ reduction in nodule number. This shows that secretion systems are not essential for effective nodulation. If the T3SS has a negative effect on nodulation, then knocking out the T3SS or T4SS results in a gain of function phenotype, where the strain is now able for form nodules on a host genotype that it was previously unable to nodulate effectively. This shows that secretion systems restrict host range. Taken together, the evidence suggests that effector proteins may act in a pathogenic manner. The function of most effector proteins are not known. Many are predicted to modify in planta protein levels, and NopL was shown to suppress defense responses. This suggest that rhizobial effector proteins act in a pathogenic manner, similar to the function of other known bacterial effector proteins (Shames and Finlay, 2012).

The model we propose here (Figure 1), is to demonstrate three points regarding effector proteins: (1) the role of effector proteins is strictly pathogenic, and not involved in symbiosis communication between the rhizobia and host; (2) the role of effector proteins may lead to an increase nodule number. $\mathrm{AON}$ is the plants system for regulating nodule number. The mechanism of action for individual effector proteins will differ, but the unifying aspect is the increase in nodule number. This increase could be achieved through forming additional nodules or the prevention of nodule senescence; and (3) plants use $\mathrm{R}$ genes to recognize effector proteins. This recognition results in host defense responses, which can prevent nodulation. This serves to establish a host range for rhizobial strains possessing effector proteins which are recognized by the host.

\section{Conclusion}

The T3SS, T4SS, and T6SS all play an important role in nodule formation in the symbiosis between rhizobia and legumes. Many studies have shown that these secretion systems have an effect on host range. NFs and surface polysaccharides are also known to effect symbiotic host range. These factors are important for host recognition of a symbiont versus a pathogen and facilitate infection for nodule formation. However, pathogens use effector proteins during invasion to promote virulence, and these effectors have an effect on the pathogens host range. Thus, other factors besides host range have to be used to determine the

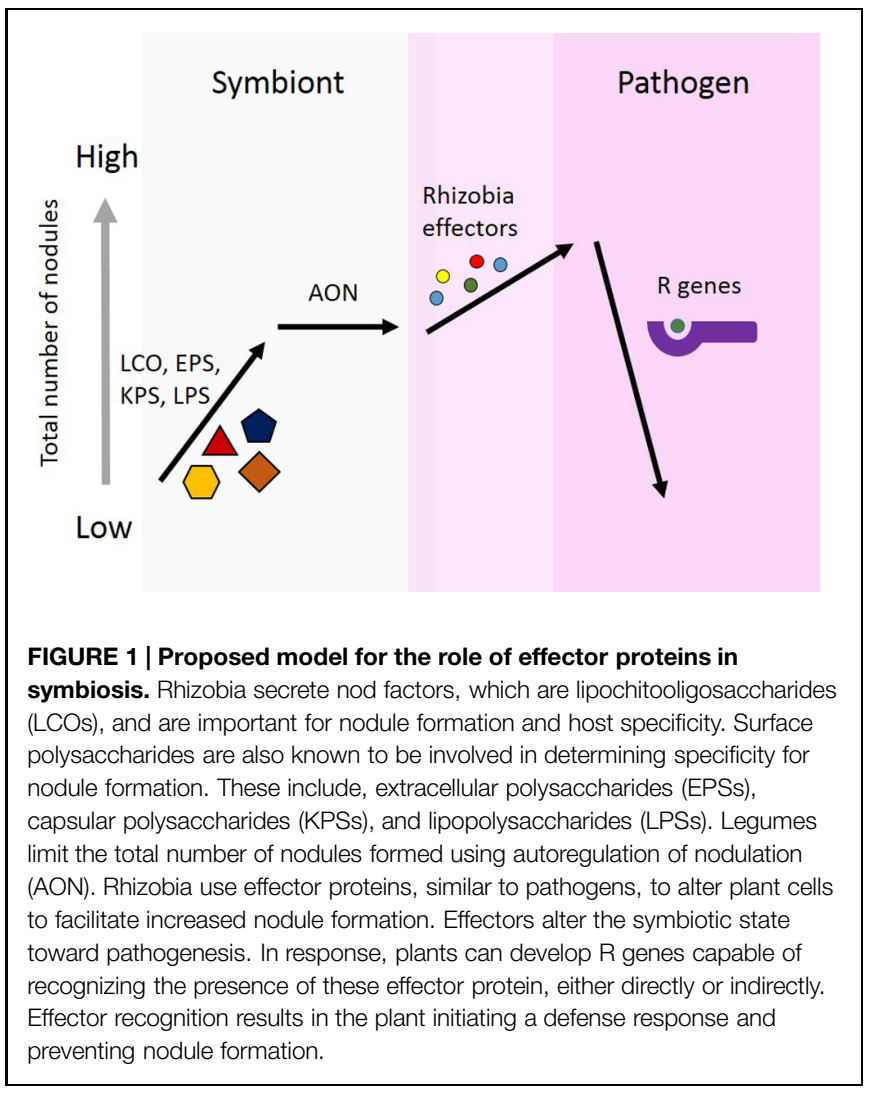

role of secretion systems in rhizobia/plant interaction. The T3SS, T4SS, and T6SS are all known to transport effector proteins. The predicted function of these proteins in planta, plus identifying $\mathrm{R}$ genes which respond to the T3SS or its effectors, strongly suggest that these secretion systems are acting in a pathogenic manner.

These secretion systems function to transport proteins from rhizobia into the plant cytosol. Once in the cytosol, they act to either increase nodulation or result in decreased nodulation through plant defense recognition. Specific changes in planta are not yet known. Identifying how rhizobia use effector protein could have an important agricultural application. Rhizobia may be using these proteins to suppress or prevent AON, and manipulation of this regulation may lead to the development of new strategies for increasing nodule formation. These effector proteins still have not been expressed in planta, in legumes, and thus their functions remain unclear. Although several hypotheses have been postulated, the role of T3SS and T4SS are still not fully understood and warrant further research.

\section{Acknowledgments}

We thank Chris Staley for helpful comments. The work was supported, in part, by grant 1237993 from the National Science Foundation. 


\section{References}

Angot, A., Peeters, N., Lechner, E., Vailleau, F., Baud, C., Gentzbittel, L., et al. (2006). Ralstonia solanacearum requires F-box-like domain-containing type III effectors to promote disease on several host plants. Proc. Natl. Acad. Sci. U.S.A. 103, 14620-14625. doi: 10.1073/pnas.0509393103

Bartsev, A. V., Boukli, N. M., Deakin, W. J., Staehelin, C., and Broughton, W. J. (2003). Purification and phosphorylation of the effector protein NopL from Rhizobium sp. NGR234. FEBS Lett. 554, 271-274. doi: 10.1016/S00145793(03)01145-1

Bartsev, A. V., Deakin, W. J., Boukli, N. M., Mcalvin, C. B., Stacey, G., Broughton, W. J., et al. (2004). NopL, an effector protein of Rhizobium sp. NGR234, thwarts activation of plant defense reactions 1. Plant Physiol. 134, 871-879. doi: 10.1104/pp.103.031740

Belkhadir, Y., Subramaniam, R., and Dangl, J. L. (2004). Plant disease resistance protein signaling: NBS-LRR proteins and their partners. Curr. Opin. Plant Biol. 7, 391-399. doi: 10.1016/j.pbi.2004.05.009

Bingle, L. E., Bailey, C. M., and Pallen, M. J. (2008). Type VI secretion: a beginner's guide. Curr. Opin. Microbiol. 11, 3-8. doi: 10.1016/j.mib.2008.01.006

Bladergroen, M. R., Badelt, K., and Spaink, H. P. (2003). Infection-blocking genes of a symbiotic Rhizobium leguminosarum strain that are involved in temperature-dependent protein secretion. Mol. Plant Microbe Interact. 16, 53-64. doi: 10.1094/MPMI.2003.16.1.53

Broughton, W. J., Hanin, M., Relić, B., Kopciñska, J., Golinowski, W., Şimşek, Ş., et al. (2006). Flavonoid-inducible modifications to rhamnan $\mathrm{O}$ antigens are necessary for Rhizobium sp. strain NGR234-legume symbioses. J. Bacteriol. 188, 3654-3663. doi: 10.1128/JB.188.10.3654-3663.2006

Cascales, E., and Christie, P. J. (2003). The versatile bacterial type IV secretion systems. Nat. Rev. Microbiol. 1, 137-49. doi: 10.1038/nrmicro753

Dai, W. J., Zeng, Y., Xie, Z. P., and Staehelin, C. (2008). Symbiosis-promoting and deleterious effects of NopT, a novel type 3 effector of Rhizobium sp. strain NGR234. J. Bacteriol. 190, 5101-5110. doi: 10.1128/JB.00306-8

Deakin, W. J., and Broughton, W. J. (2009). Symbiotic use of pathogenic strategies: rhizobial protein secretion systems. Nat. Rev. Microbiol. 7, 312-20. doi: 10.1038/nrmicro2091

Deakin, W. J., Marie, C., Saad, M. M., Krishnan, H. B., and Broughton, W. J. (2005). NopA is associated with cell surface appendages produced by the type III secretion system of Rhizobium sp. strain NGR234. Mol. Plant Microbe Interact. 18, 499-507. doi: 10.1094/MPMI-18-9

De Lyra, M. D. C. C. P., López-Baena, F. J., Madinabeitia, N., Vinardell, J. M., Espuny, M. D. R., Cubo, M. T., et al. (2006). Inactivation of the Sinorhizobium fredii $\mathrm{HH} 103$ rhcJ gene abolishes nodulation outer proteins (Nops) secretion and decreases the symbiotic capacity with soybean. Int. Microbiol. 9, 125-133.

Dénarié, J., Debellé, F., and Promé, J. C. (1996). Rhizobium lipochitooligosaccharide nodulation factors: signaling molecules mediating recognition and morphogenesis. Annu. Rev. Biochem. 65, 503-535. doi: 10.1146/annurev.biochem.65.1.503

de Souza, J. A. M., Tieppo, E., de Souza Magnani, G., Alves, L. M. C., Cardoso, R. L., Cruz, L. M., et al. (2012). Draft genome sequence of the nitrogen-fixing symbiotic bacterium Bradyrhizobium elkanii 587. J. Bacteriol. 194, 3547-3548. doi: $10.1128 /$ JB.00563-2

Dodds, P. N., and Rathjen, J. P. (2010). Plant immunity: towards an integrated view of plant-pathogen interactions. Nat. Rev. Genet. 11, 539-548. doi: $10.1038 / \mathrm{nrg} 2812$

Endre, G., Kereszt, A., Kevei, Z., Mihacea, S., Kalo, P., and Kiss, G. B. (2002). A receptor kinase gene regulating symbiotic nodule development. Nature 417, 962-966. doi: 10.1038/nature00842

Esseling, J. J., Lhuissier, F. G. P., and Emons, A. M. C. (2003). Nod factorinduced root hair curling: continuous polar growth towards the point of nod factor application. Plant Physiol. 132, 1982-1988. doi: 10.1104/pp.103. 021634

Fauvart, M., and Michiels, J. (2008). Rhizobial secreted proteins as determinants of host specificity in the Rhizobium-legume symbiosis. FEMS Microbiol. Lett. 285, 1-9. doi: 10.1111/j.1574-6968.2008.01254.x

Ferguson, B. J., Indrasumunar, A., Hayashi, S., Lin, M. H., Lin, Y. H., Reid, D. E., et al. (2010). Molecular analysis of legume nodule development and autoregulation. J. Integr. Plant Biol. 52, 61-76. doi: 10.1111/j.17447909.2010.00899.x
Fotiadis, C. T., Dimou, M., Georgakopoulos, D. G., Katinakis, P., and Tampakaki, A. P. (2012). Functional characterization of NopT1 and NopT2, two type III effectors of Bradyrhizobium japonicum. FEMS Microbiol. Lett. 327, 66-77. doi: 10.1111/j.1574-6968.2011.02466.x

Fournier, J., Teillet, A., Chabaud, M., Ivanov, S., Genre, A., Limpens, E., et al. (2015). Remodeling of the infection chamber prior to infection thread formation reveals a two-step mechanism for rhizobial entry into the host legume root hair. Plant Physiol. 167, 1233-12342. doi: 10.1104/pp.114. 253302

Gage, D. J. (2004). Infection and invasion of roots by symbiotic, nitrogen-fixing rhizobia during nodulation of temperate legumes. Microbiol. Mol. Biol. Rev. 68, 280-300. doi: 10.1128/MMBR.68.2.280-300.2004

Gazi, A. D., Sarris, P. F., Fadouloglou, V. E., Charova, S. N., Mathioudakis, N., Panopoulos, N. J., et al. (2012). Phylogenetic analysis of a gene cluster encoding an additional, rhizobial-like type III secretion system that is narrowly distributed among Pseudomonas syringae strains. BMC Microbiol. 12:188. doi: 10.1186/1471-2180-12-188

Ghosh, P. (2004). Process of protein transport by the type III secretion system. Society 68, 771-795. doi: 10.1128/MMBR.68.4.771

Giraud, E., Moulin, L., Vallenet, D., Barbe, V., Cytryn, E., Avarre, J.-C., et al. (2007). Legumes symbioses: absence of Nod genes in photosynthetic bradyrhizobia. Science 316, 1307-1312. doi: 10.1126/science. 1139548

Göhre, V., Spallek, T., Häweker, H., Mersmann, S., Mentzel, T., Boller, T., et al. (2008). Plant pattern-recognition receptor FLS2 is directed for degradation by the bacterial ubiquitin ligase AvrPtoB. Curr. Biol. 18, 1824-1832. doi: 10.1016/j.cub.2008.10.063

González, E. M., Aparicio-tejo, P. M., Gordon, A. J., Minchin, F. R., Royuela, M., and Arrese-igor, C. (1998). Water-deficit effects on carbon and nitrogen metabolism of pea nodules. J. Exp. Bot. 49, 1705-1714. doi: $10.1093 / \mathrm{jxb} / 49.327 .1705$

Goormachtig, S., Capoen, W., and Holsters, M. (2004). Rhizobium infection: lessons from the versatile nodulation behaviour of water-tolerant legumes. Trends Plant Sci. 9, 518-522. doi: 10.1016/j.tplants.2004.09.005

Hansen, G., Das, A., and Chilton, M. D. (1994). Constitutive expression of the virulence genes improves the efficiency of plant transformation by Agrobacterium. Proc. Natl. Acad. Sci. U.S.A. 91, 7603-7607. doi: 10.1073/pnas.91.16.7603

Hassan, S., and Mathesius, U. (2012). The role of flavonoids in rootrhizosphere signalling: opportunities and challenges for improving plant-microbe interactions. J. Exp. Bot. 63, 3429-44. doi: 10.1093/jxb/ err430

Hernández-Jiménez, M. J., Mercedes Lucas, M., and de Felipe, M. R. (2002). Antioxidant defence and damage in senescing lupin nodules. Plant Physiol. Biochem. 40, 645-657. doi: 10.1016/S0981-9428(02)01422-5

Herridge, D., and Rose, I. (2000). Breeding for enhanced nitrogen fixation in crop legumes. F. Crop. Res. 65, 229-248. doi: 10.1016/S0378-4290(99)00089-1

Hotson, A., Chosed, R., Shu, H., Orth, K., and Mudgett, M. B. (2003). Xanthomonas type III effector XopD targets SUMO-conjugated proteins in planta. Mol. Microbiol. 50, 377-389. doi: 10.1046/j.1365-2958.2003.03730.x

Howieson, J. G. (1995). Rhizobial persistence and its role in the development of sustainable agricultural systems in Mediterranean environments. Soil Biol. Biochem. 27, 603-610. doi: 10.1016/0038-0717(95)98638-5

Hubber, A. M., Sullivan, J. T., and Ronson, C. W. (2007). Symbiosis-induced cascade regulation of the Mesorhizobium loti R7A VirB/D4 type IV secretion system. Mol. Plant Microbe Interact. 20, 255-261. doi: 10.1094/MPMI-20-30255

Hubber, A., Vergunst, A. C., Sullivan, J. T., Hooykaas, P. J. J., and Ronson, C. W. (2004). Symbiotic phenotypes and translocated effector proteins of the Mesorhizobium loti strain R7A VirB / D4 type IV secretion system. Mol. Microbiol. 54, 561-574. doi: 10.1111/j.1365-2958.2004.04292.x

Jones, J. D. G., and Dangl, J. L. (2006). The plant immune system. Nature 444, 323-329. doi: 10.1038 /nature 05286

Jones, K. M., Kobayashi, H., Davies, B. W., Taga, M. E., and Walker, G. C. (2007). How rhizobial symbionts invade plants: the Sinorhizobium-Medicago model. Nat. Rev. Microbiol. 5, 619-633. doi: 10.1038/nrmicro1705

Kambara, K., Ardissone, S., Kobayashi, H., Saad, M. M., Schumpp, O., Broughton, W. J., et al. (2009). Rhizobia utilize pathogen-like effector proteins during symbiosis. Mol. Microbiol. 71, 92-106. doi: 10.1111/j.1365-2958.2008.06507.x 
Kiers, E. T., Rousseau, R. A., West, S. A., and Denison, R. F. (2003). Host sanctions and the legume-Rhizobium mutualism. Nature 425, 78-81. doi: 10.1038 /nature01931

Kimbrel, J. A., Thomas, W. J., Jiang, Y., Creason, A. L., Thireault, C. A., Sachs, J. L., et al. (2013). Mutualistic co-evolution of type III effector genes in Sinorhizobium fredii and Bradyrhizobium japonicum. PLoS Pathog. 9:e1003204. doi: 10.1371/journal.ppat.1003204

Kobayashi, H., Naciri-Graven, Y., Broughton, W. J., and Perret, X. (2004). Flavonoids induce temporal shifts in gene-expression of nod-box controlled loci in Rhizobium sp. NGR234. Mol. Microbiol. 51, 335-347. doi: 10.1046/j.13652958.2003.03841.x

Krause, A., Doerfel, A., and Göttfert, M. (2002). Mutational and transcriptional analysis of the type III secretion system of Bradyrhizobium japonicum. Mol. Plant Microbe Interact. 15, 1228-1235. doi: 10.1094/MPMI.2002.15.12.1228

Krishnan, H. B., Lorio, J., Kim, W. S., Jiang, G., Kim, K. Y., DeBoer, M., et al. (2003). Extracellular proteins involved in soybean cultivar-specific nodulation are associated with pilus-like surface appendages and exported by a type III protein secretion system in Sinorhizobium fredii USDA257. Mol. Plant Microbe Interact. 16, 617-625. doi: 10.1094/MPMI.2003.16.7.617

Krusell, L., Madsen, L. H., Sato, S., Aubert, G., Genua, A., Szczyglowski, K., et al. (2002). Shoot control of root development and nodulation is mediated by a receptor-like kinase. Nature 420, 422-426. doi: 10.1038/nature01207

Kuldau, G. A., De Vos, G., Owen, J., McCaffrey, G., and Zambryski, P. (1990). The virB operon of Agrobacterium tumefaciens pTiC58 encodes 11 open reading frames. Mol. Gen. Genet. 221, 256-266. doi: 10.1007/BF00261729

Lindeberg, M., Myers, C. R., Collmer, A., and Schneider, D. J. (2008). Roadmap to new virulence determinants in Pseudomonas syringae: insights from comparative genomics and genome organization. Mol. Plant Microbe Interact. 21, 685-700. doi: 10.1094/MPMI-21-6-0685

Lodwig, E. M., Hosie, A. H. F., Bourdes, A., Findlay, K., Allaway, D., Karunakaran, R., et al. (2006). Amino-acid cycling drives nitrogen fixation in the legume - Rhizobium symbiosis. Nature 422, 722-726. doi: 10.1038/nature01549.1

Long, S. R. (1996). Rhizobium symbiosis: nod factors in perspective. Plant Cell 8, 1885-1898. doi: 10.1105/tpc.8.10.1885

López-Baena, F. J., Vinardell, J. M., Pérez-Montaño, F., Crespo-Rivas, J. C., Bellogín, R. A., Espuny, M. D. R., et al. (2008). Regulation and symbiotic significance of nodulation outer proteins secretion in Sinorhizobium fredii HH103. Microbiology 154, 1825-1836. doi: 10.1099/mic.0.2007/016337-16330

Lorio, J. C., Kim, W. S., and Krishnan, H. B. (2004). NopB, a soybean cultivar-specificity protein from Sinorhizobium fredii USDA257, is a type III secreted protein. Mol. Plant Microbe Interact. 17, 1259-1268. doi: 10.1094/MPMI.2004.17.11.1259

Macho, A. P., and Zipfel, C. (2015). Science direct targeting of plant pattern recognition receptor- triggered immunity by bacterial type-III secretion system effectors. Curr. Opin. Microbiol. 23, 14-22. doi: 10.1016/j.mib.2014.10.009

Marchetti, M., Capela, D., Glew, M., Cruveiller, S., Chane-Woon-Ming, B., Gris, C., et al. (2010). Experimental evolution of a plant pathogen into a legume symbiont. PLoS Biol. 8:e1000280. doi: 10.1371/journal.pbio.1000280

Marie, C., Deakin, W. J., Ojanen-Reuhs, T., Diallo, E., Reuhs, B., Broughton, W. J., et al. (2004). TtsI, a key regulator of Rhizobium species NGR234 is required for type III-dependent protein secretion and synthesis of rhamnose-rich polysaccharides. Mol. Plant Microbe Interact. 17, 958-966. doi: 10.1094/MPMI.2004.17.9.958

Masson-Boivin, C., Giraud, E., Perret, X., and Batut, J. (2009). Establishing nitrogen-fixing symbiosis with legumes: how many Rhizobium recipes? Trends Microbiol. 17, 458-466. doi: 10.1016/j.tim.2009.07.004

Matamoros, M. A., Baird, L. M., Escuredo, P. R., Dalton, D. A., Minchin, F. R., Iturbe-Ormaetxe, I., et al. (1999). Stress-induced legume root nodule senescence. Physiological, biochemical, and structural alterations. Plant Physiol. 121, 97-112. doi: 10.1104/pp.121.1.97

Matsunami, T., Kaihatsu, A., Maekawa, T., Takahashi, M., and Kokubun, M. (2004). Characterization of vegetative growth of a supernodulating soybean genotype, sakukei 4. Plant Prod. Sci. 7, 165-171. doi: 10.1626/pps.7.165

Mergaert, P., Uchiumi, T., Alunni, B., Evanno, G., Cheron, A., Catrice, O., et al. (2006). Eukaryotic control on bacterial cell cycle and differentiation in the Rhizobium-legume symbiosis. Proc. Natl. Acad. Sci. U.S.A. 103, 5230-5235. doi: $10.1073 /$ pnas.0600912103
Michiels, J., Pelemans, H., Vlassak, K., Verreth, C., and Vanderleyden, J. (1995). Identification and characterization of a Rhizobium leguminosarum bv. phaseoli gene that is important for nodulation competitiveness and shows structural homology to a Rhizobium fredii host-inducible gene. Mol. Plant Microbe Interact. 8, 468-472. doi: 10.1094/MPMI-8-0468

Mortier, V., Holsters, M., and Goormachtig, S. (2012). Never too many? How legumes control nodule numbers. Plant Cell Environ. 35, 245-258. doi: 10.1111/j.1365-3040.2011.02406.x

Nimchuk, Z., Marois, E., Kjemtrup, S., Leister, R. T., Katagiri, F., and Dangl, J. L. (2000). Eukaryotic fatty acylation drives plasma membrane targeting and enhances function of several type III effector proteins from Pseudomonas syringae. Cell 101, 353-363. doi: 10.1016/S0092-8674(00)80846-6

Nishimura, R., Hayashi, M., Wu, G.-J., Kouchi, H., Imaizumi-Anraku, H., Murakami, Y., et al. (2002). HAR1 mediates systemic regulation of symbiotic organ development. Nature 420, 426-429. doi: 10.1038/nature01231

Okamoto, S., Shinohara, H., Mori, T., Matsubayashi, Y., and Kawaguchi, M. (2013). Root-derived CLE glycopeptides control nodulation by direct binding to HAR1 receptor kinase. Nat. Commun. 4:2191. doi: 10.1038/ncomms3191

Okazaki, S., Kaneko, T., Sato, S., and Saeki, K. (2013). Hijacking of leguminous nodulation signaling by the rhizobial type III secretion system. Proc. Natl. Acad. Sci. U.S.A. 110, 17131-17136. doi: 10.1073/pnas.1302360110

Okazaki, S., Okabe, S., Higashi, M., Shimoda, Y., Sato, S., Tabata, S., et al. (2010). Identification and functional analysis of type III effector proteins in Mesorhizobium loti. Mol. Plant Microbe Interact. 23, 223-234. doi: 10.1094/MPMI-23-2-0223

Okazaki, S., Zehner, S., Hempel, J., Lang, K., and Göttfert, M. (2009). Genetic organization and functional analysis of the type III secretion system of Bradyrhizobium elkanii. FEMS Microbiol. Lett. 295, 88-95. doi: 10.1111/j.15746968.2009.01593.x

Oldroyd, G. E. D., and Downie, J. A. (2008). Coordinating nodule morphogenesis with rhizobial infection in legumes. Annu. Rev. Plant Biol. 59, 519-546. doi: 10.1146/annurev.arplant.59.032607.092839

Oldroyd, G. E. D., Murray, J. D., Poole, P. S., and Downie, J. A. (2011). The rules of engagement in the legume-rhizobial symbiosis. Annu. Rev. Genet. 45, 119-144. doi: 10.1146/annurev-genet-110410-9

Pedley, K. F., and Martin, G. B. (2005). Role of mitogen-activated protein kinases in plant immunity. Curr. Opin. Plant Biol. 8, 541-547. doi: 10.1016/j.pbi.2005.07.006

Perret, X., Staehelin, C., and Broughton, W. J. (2000). Molecular basis of symbiotic promiscuity. Microbiol. Mol. Biol. Rev. 64, 180-201. doi: 10.1128/MMBR.64.1.180-201.2000

Prell, J., White, J. P., Bourdes, A., Bunnewell, S., Bongaerts, R. J., and Poole, P. S. (2009). Legumes regulate Rhizobium bacteroid development and persistence by the supply of branched-chain amino acids. Proc. Natl. Acad. Sci. U.S.A. 106, 12477-12482. doi: 10.1073/pnas.0903653106

Puppo, A., Groten, K., Bastian, F., Carzaniga, R., Soussi, M., Lucas, M. M., et al. (2005). Legume nodule senescence: roles for redox and hormone signalling in the orchestration of the natural aging process. New Phytol. 165, 683-701. doi: 10.1111/j.1469-8137.2004.01285.x

Puri, N., Jenner, C., Bennett, M., Stewart, R., Mansfield, J., Lyons, N., et al. (1997). Expression of avrPphB, an avirulence gene from Pseudomonas syringae pv. phaseolicola, and the delivery of signals causing the hypersensitive reaction in bean. Mol. Plant Microbe Interact. 10, 247-256. doi: 10.1094/MPMI.1997.10.2.247

Radutoiu, S., Madsen, L. H., Madsen, E. B., Jurkiewicz, A., Fukai, E., Quistgaard, E. M. H., et al. (2007). LysM domains mediate lipochitin-oligosaccharide recognition and $\mathrm{Nfr}$ genes extend the symbiotic host range. EMBO J. 26, 3923-3935. doi: 10.1038/sj.emboj.7601826

Reid, D. E., Ferguson, B. J., and Gresshoff, P. M. (2011). Inoculation- and nitrateinduced CLE peptides of soybean control NARK-dependent nodule formation. Mol. Plant Microbe Interact. 24, 606-618. doi: 10.1094/MPMI-09-10-0207

Reid, D. E., Li, D., Ferguson, B. J., and Gresshoff, P. M. (2013). Structure-function analysis of the GmRIC1 signal peptide and CLE domain required for nodulation control in soybean. J. Exp. Bot. 64, 1575-1585. doi: 10.1093/jxb/ert008

Rodrigues, J. A., López-Baena, F. J., Ollero, F. J., Vinardell, J. M., Espuny, M. D. R., Bellogín, R. A., et al. (2007). NopM and NopD are rhizobial nodulation outer proteins: identification using LC-MALDI and LC-ESI with a monolithic capillary column. J. Proteome Res. 6, 1029-1037. doi: 10.1021/pr060519f 
Saad, M. M., Crèvecoeur, M., Masson-Boivin, C., and Perret, X. (2012). The type 3 protein secretion system of Cupriavidus taiwanensis strain LMG19424 compromises symbiosis with Leucaena leucocephala. Appl. Environ. Microbiol. 78, 7476-7479. doi: 10.1128/AEM.01691-2

Saad, M. M., Kobayashi, H., Marie, C., Brown, I. R., Mansfield, J. W., Broughton, W. J., et al. (2005). NopB, a type III secreted protein of Rhizobium sp. strain NGR234, is associated with pilus-like surface appendages. Society 187, 11731181. doi: 10.1128/JB.187.3.1173

Saad, M. M., Staehelin, C., Broughton, W. J., and Deakin, W. J. (2008) Protein-protein interactions within type III secretion system-dependent pili of Rhizobium sp. strain NGR234. J. Bacteriol. 190, 750-754. doi: 10.1128/JB. 01116-7

Saeki, K. (2011). Rhizobial measures to evade host defense strategies and endogenous threats to persistent symbiotic nitrogen fixation: a focus on two legume-Rhizobium model systems. Cell. Mol. Life Sci. 68, 1327-1339. doi: 10.1007/s00018-011-0650-5

Sánchez, C., Iannino, F., Deakin, W. J., Ugalde, R. A., and Lepek, V. C. (2009). Characterization of the Mesorhizobium loti MAFF303099 type-three protein secretion system. Mol. Plant Microbe Interact. 22, 519-528. doi: 10.1094/MPMI22-5-0519

Sánchez, C., Mercante, V., Babuin, M. F., and Lepek, V. C. (2012). Dual effect of Mesorhizobium loti T3SS functionality on the symbiotic process. FEMS Microbiol. Lett. 330, 148-156. doi: 10.1111/j.1574-6968.2012.02545.x

Sasaki, T., Suzaki, T., Soyano, T., Kojima, M., Sakakibara, H., and Kawaguchi, M. (2014). Shoot-derived cytokinins systemically regulate root nodulation. Nat. Commun. 5, 1-9. doi: 10.1038/ncomms5983

Schell, M. A., Ulrich, R. L., Ribot, W. J., Brueggemann, E. E., Hines, H. B., Chen, D., et al. (2007). Type VI secretion is a major virulence determinant in Burkholderia mallei. Mol. Microbiol. 64, 1466-1485. doi: 10.1111/j.1365-2958.2007.05734.x

Schrammeijer, B., Risseeuw, E., Pansegrau, W., Regensburg-Tuïnk, T. J., Crosby, W. L., and Hooykaas, P. J. (2001). Interaction of the virulence protein VirF of Agrobacterium tumefaciens with plant homologs of the yeast Skp1 protein. Curr. Biol. 11, 258-262. doi: 10.1016/S0960-9822(01)00069-0

Shames, S. R., and Finlay, B. B. (2012). Bacterial effector interplay: a new way to view effector function. Trends Microbiol. 20, 214-219. doi: 10.1016/j.tim.2012.02.007

Shan, L., He, P., Li, J., Heese, A., Peck, S. C., Nürnberger, T., et al. (2008). Bacterial effectors target the common signaling partner BAK1 to disrupt multiple MAMP receptor-signaling complexes and impede plant immunity. Cell Host Microbe 4, 17-27. doi: 10.1016/j.chom.2008.05.017

Shao, F., Merritt, P. M., Bao, Z., Innes, R. W., and Dixon, J. E. (2002). A Yersinia effector and a Pseudomonas avirulence protein define a family of cysteine proteases functioning in bacterial pathogenesis. Cell 109, 575-588. doi: 10.1016/S0092-8674(02)00766-3

Skorpil, P., Saad, M. M., Boukli, N. M., Kobayashi, H., Ares-Orpel, F., Broughton, W. J., et al. (2005). NopP, a phosphorylated effector of Rhizobium sp. strain NGR234, is a major determinant of nodulation of the tropical legumes Flemingia congesta and Tephrosia vogelii. Mol. Microbiol. 57, 1304-1317. doi: 10.1111/j.1365-2958.2005.04768.x

Stachel, S. E., and Zambryski, P. C. (1986). virA and virG control the plant-induced activation of the T-DNA transfer process of A. tumefaciens. Cell 46, 325-333. doi: 10.1016/0092-8674(86)90653-7

Sugawara, M., Epstein, B., Badgley, B., Unno, T., Xu, L., Reese, J., et al. (2013). Comparative genomics of the core and accessory genomes of 48 Sinorhizobium strains comprising five genospecies. Genome Biol. 14:R17. doi: 10.1186/gb2013-14-2-r17

Suzaki, T., Yoro, E., and Kawaguchi, M. (2015). Leguminous plants: inventors of root Nodules to accommodate symbiotic bacteria. Int. Rev. Cell Mol. Biol. 316, 111-158. doi: 10.1016/bs.ircmb.2015.01.004

Takahara, M., Magori, S., Soyano, T., Okamoto, S., Yoshida, C., Yano, K., et al. (2013). TOO MUCH LOVE, a novel kelch repeat-containing F-box protein, functions in the long-distance regulation of the Legume-Rhizobium symbiosis. Plant Cell Physiol. 54, 433-447. doi: 10.1093/pcp/pct022

Takahashi, M., Arihara, J., Nakayama, N., and Kokubun, M. (2003). Characteristics of growth and yield formation in the improved genotype of supernodulating soybean (Glycine max L. Merr.). Plant Prod. Sci. 6, 112-118. doi: $10.1626 /$ pps.6.112

Tampakaki, A. P. (2014). Commonalities and differences of T3SSs in rhizobia and plant pathogenic bacteria. Front. Plant Sci. 5:114. doi: 10.3389/fpls.2014.00114
Trese, A. (1995). A single dominant gene in McCall soybean prevents effective nodulation with Rhizobium fredii USDA257. Euphytica 81, 279-282. doi: 10.1007/BF00025618

Tseng, T.-T., Tyler, B. M., and Setubal, J. C. (2009). Protein secretion systems in bacterial-host associations, and their description in the Gene Ontology. BMC Microbiol. 9(Suppl. 1):S2. doi: 10.1186/1471-2180-9-S1-S2

Tzfira, T., Vaidya, M., and Citovsky, V. (2004). Involvement of targeted proteolysis in plant genetic transformation by Agrobacterium. Nature 431, 6-11. doi: 10.1038/nature02837.1

Udvardi, M., and Poole, P. S. (2013). Transport and metabolism in legume-rhizobia symbioses. Annu. Rev. Plant Biol. 64, 781-805. doi: 10.1146/annurev-arplant050312-120235

Vasse, J., Billy, F., and Truchet, G. (1993). Abortion of infection during the Rhizobium meliloti-alfalfa symbiotic interaction is accompanied by a hypersensitive reaction. Plant J. 4, 555-566. doi: 10.1046/j.1365-313X.1993.04030555.x

Van de Velde, W., Zehirov, G., Szatmari, A., Debreczeny, M., Ishihara, H., Kevei, Z., et al. (2010). Plant peptides govern terminal differentiation of bacteria in symbiosis. Science 327, 1122-1126. doi: 10.1126/science.1184057

Vergunst, A. C., Schrammeijer, B., den Dulk-Ras, A., de Vlaam, C. M. T., Regensburg-Tuïnk, T. J. G., and Hooykaas, P. J. J. (2000). VirB/D4-dependent protein translocation from Agrobacterium into plant cells. Science 290, 979-982. doi: 10.1126/science.290.5493.979

Vergunst, A. C., van Lier, M. C. M., den Dulk-Ras, A., Stüve, T. A. G., Ouwehand, A., and Hooykaas, P. J. J. (2005). Positive charge is an important feature of the C-terminal transport signal of the VirB/D4-translocated proteins of Agrobacterium. Proc. Natl. Acad. Sci. U.S.A. 102, 832-837. doi: 10.1073/pnas.0406241102

Viprey, V., Del Greco, A., Golinowski, W., Broughton, W. J., and Perret, X. (1998). Symbiotic implications of type III protein secretion machinery in Rhizobium. Mol. Microbiol. 28, 1381-1389. doi: 10.1046/j.1365-2958.1998.00920.x

Wang, D., Yang, S., Tang, F., and Zhu, H. (2012). Symbiosis specificity in the legume - rhizobial mutualism. Cell. Microbiol. 14, 334-342. doi: 10.1111/j.14625822.2011.01736.x

Wassem, R., Kobayashi, H., Kambara, K., Le Quéré, A., Walker, G. C., Broughton, W. J., et al. (2008). TtsI regulates symbiotic genes in Rhizobium species NGR234 by binding to tts boxes. Mol. Microbiol. 68, 736-748. doi: 10.1111/j.13652958.2008.06187.x

Wenzel, M., Friedrich, L., Göttfert, M., and Zehner, S. (2010). The type III-secreted protein NopE1 affects symbiosis and exhibits a calcium-dependent autocleavage activity. Mol. Plant Microbe Interact. 23, 124-129. doi: 10.1094/MPMI-23-10124

Wooldridge, K. (2009). Bacterial Secreted Proteins: Secretory Mechanisms and Role in Pathogenesis. Poole: Caister Academic Press.

Xin, D. W., Liao, S., Xie, Z. P., Hann, D. R., Steinle, L., Boller, T., et al. (2012). Functional analysis of NopM, a novel E3 ubiquitin ligase (NEL) domain effector of Rhizobium sp. strain NGR234. PLoS Pathog. 8:e1002707. doi: 10.1371/journal.ppat.1002707

Yang, S., Tang, F., Gao, M., Krishnan, H. B., and Zhu, H. (2010). R gene-controlled host specificity in the legume-rhizobia symbiosis. Proc. Natl. Acad. Sci. U.S.A. 107, 18735-18740. doi: 10.1073/pnas.1011957107

Zhang, L., Chen, X. J., Lu, H. B., Xie, Z. P., and Staehelin, C. (2011). Functional analysis of the type 3 effector nodulation outer protein L (NopL) from Rhizobium sp. NGR234: symbiotic effects, phosphorylation, and interference with mitogen-activated protein kinase signaling. J. Biol. Chem. 286, 3217832187. doi: 10.1074/jbc.M111.265942

Zupan, J. R., and Zambryski, P. (1995). Transfer of T-DNA from Agrobacterium to the plant cell. Plant Physiol. 107, 1041-1047. doi: 10.1104/pp.107.4.1041

Conflict of Interest Statement: The authors declare that the research was conducted in the absence of any commercial or financial relationships that could be construed as a potential conflict of interest.

Copyright (c) 2015 Nelson and Sadowsky. This is an open-access article distributed under the terms of the Creative Commons Attribution License (CC BY). The use, distribution or reproduction in other forums is permitted, provided the original author(s) or licensor are credited and that the original publication in this journal is cited, in accordance with accepted academic practice. No use, distribution or reproduction is permitted which does not comply with these terms. 